Acta Agroph., 2018, 25(4), 397-407

doi: $10.31545 /$ aagr/99073

\title{
YIELD OF DRY MATTER AND STARCH OF EDIBLE POTATO TUBERS IN CONDITIONS OF APPLICATION OF GROWTH BIOSTIMULATORS AND HERBICIDE
}

\author{
Alicja Joanna Baranowska \\ Department of Agriculture, Institute of Agriculture \\ Pope John II State School of Higher Education in Biala Podlaska \\ ul. Sidorska 95/97, 21-500 Biała Podlaska, Poland \\ e-mail: alabar@tlen.pl
}

Abstract. Field experiments were conducted in the years 2015-2017 in the region of eastern Poland, in the Biała Podlaska Commune $\left(52^{\circ} 02^{\prime} \mathrm{N}, 23^{\circ} 07^{\prime} \mathrm{E}\right)$ in the Lublin Voivodeship. The purpose of the study was to assess the effect of five methods of treatment involving application of growth biostimulators and herbicide on the yield of dry matter and starch of edible potato tubers. The experiments were performed in three replicates using the randomised split-block method. The examined factors included: factor I - three early cultivars of edible potato (Owacja, Bellarosa, Vineta), factor II - doses and dates of application of growth biostimulators: GreenOK-Universal Pro and Asahi SL as well as their combination with the Avatar $293 \mathrm{ZC}$ herbicide. The highest yield of dry matter and starch of tubers was obtained from treatment 4 where, prior to sprouting, mechanical treatment was used, and after the final shaping of ridges and just before sprouting the Avatar $293 \mathrm{ZC}$ herbicide at a dose of $1.5 \mathrm{dm}^{3} \mathrm{ha}^{-1}$, and then after sprouting the GreenOK Universal-PRO was applied three times at doses: $0.10 \mathrm{dm}^{3} \mathrm{ha}^{-1}$ - peak-end of sprouting $+0.15 \mathrm{dm}^{3} \mathrm{ha}^{-1}$ - covering of interrows $+0.15 \mathrm{dm}^{3} \mathrm{ha}^{-1}$ - flower bud break (the mean yield of dry matter was at the level of $9.0 \mathrm{t} \mathrm{ha}^{-1}$ and that of starch at the level of $6.3 \mathrm{t} \mathrm{ha}^{-1}$. However, the lowest yield of nutrients of potato tubers was obtained from the treatment where only mechanical treatment was used (treatment 1). Potato cultivars cultivated in the experiment and meteorological conditions also had a significant impact on the size of the yield of dry matter and starch of tubers. Growth biostimulators should find a wider application in agricultural practice as they are environment-friendly preparations and their use on agricultural crop plant fields gives notable production benefits.

Keyword s: potato, treatment methods, GreenOk-Uniwersal Pro, Asahi SL, Avatar 293 ZC 


\section{INTRODUCTION}

Potato (Solanum tuberosum L.) is cultivated in about 160 countries in the world and consumed every day by over a billion people (Camire et al. 2009, Bishwoyog and Swarnima 2016). In the world production, it is an important agricultural plant, not only on account of its consumer importance, but also due to its industrial and fodder significance. Regardless of the direction of production, the content of dry matter and starch in tubers should be counted as one of the most important features determining the quality of potato (Zgórska and Grudzińska 2012). Just after harvest, potato tubers contain about $80 \%$ of water and $20 \%$ of dry matter (Lutaladio and Castaldi 2009). The content of dry matter determines nutritional value, taste value, the consistency of raw and processed tubers, and their resistance to mechanical damage (Wierzbicka 2012).

The main component of potato tubers' dry matter is starch, an indirect product of photosynthesis, hence called a renewable and biodegradable material (Leszczyński 2004). The tubers of edible potato cultivars (registered in Poland) contain from $9.9 \%$ (very early potato, Impresja cultivar) to $18.3 \%$ of starch (medium-early Asterix cultivar) (Plant Breeding... 2015). The content of starch predominantly determines the caloric value of potato which is about $70 \mathrm{kcal} 100 \mathrm{~g}^{-1}$, significantly lower than many food products (Trawczyński 2016). Starch is converted to glucose under the influence of enzymes, thus being practically fully and quickly digested in the human organism (Leszczyński 2012). The impact of starch on the consistency of boiled tubers is related to its swelling, which causes the destruction of cell structures, and with its granularity and distribution in cells (Marle et al. 1997, Lamberti et al. 2004, Rymuza et al. 2015). According to the requirements of quality features of potato fit for direct consumption, tubers should contain $18-22 \%$ of dry matter and $12-16 \%$ of starch, while potato tubers intended for chips $20-22 \%$ of dry matter and $14-17 \%$ of starch, and for crisps $20-25 \%$ of dry matter and $16-20 \%$ of starch (Lisińska 2000, Zgórska and Frydecka-Mazurczyk 2002, Grudzińska et al. 2016).

In potato production for food and industrial purposes, the content of dry matter and starch as well as the amount of produced biomass are important (Puła and Skowera 2004). The yield of starch and dry matter is a product of the yield of tubers and the content of these elements in tubers. According to Gabriel and Świeżyński (1977), the value of these features is determined in $72-92 \%$ by the yield of tubers, and only in $14-15 \%$ by the content of these elements in tubers. The level of yielding and the quality of the yield of potato tubers are determined by both cultivar properties (genetic) resulting from biological progress, and by agrotechnical and habitat conditions (Kołodziejczyk 2013, Pszczółkowski and Sawicka 2018). 
Growth biostimulators, effective microorganisms and soil fertilisers enriching the arable layer with beneficial microorganisms, improving soil properties and availability of nutrients for plants, speeding up the decomposition of natural and organic fertilisers, are currently used on a wider scale in agriculture, including also the production of potato (Paradikovic et al. 2011, Zarzecka and Gugała 2013, Maciejewski et al. 2007). Growth biostimulators are defined as preparations supporting the natural vital processes of plants and increasing the resistance of plants to stressful conditions (Maciejewski et al. 2007, Sawicka et al. 2016). According to Matyjaszczyk (2015), in 2015 on the Polish market there were around 60 biostimulators registered as plant protection products in the group "plant development and growth regulators" and around 20 biostimulators registered on the basis of fertiliser regulations as "preparations supporting plant cultivation".

Very few and rather ambiguous empirical results on the subject of the effect of growth biostimulators on the yield of dry matter and starch of table potato tubers induce to carry out further research. The aim of the experiment was to determine the effect of using five treatment methods involving the application of growth biostimulators and herbicide on the yield of dry matter and starch of three edible potato cultivars. The research hypothesis assumed that the selected care treatments involving the application of growth biostimulators and herbicide would positively impact the yield of marked quality characteristics of potato tubers.

\section{MATERIALS AND METHODS}

\section{Experiment and plant material}

The results of the field experiment conducted in the years 2015-2017 in the region of eastern Poland, in the Biała Podlaska Commune $\left(52^{\circ} 02^{\prime} \mathrm{N}, 23^{\circ} 07^{\circ} \mathrm{E}\right)$ in the Lublin Voivodeship, on an acidic light soil, were the source material. The experiment was performed in the split-plot system, in three replicates. Two factors were examined in the experiment: factor I - three early edible potato cultivars: Bellarosa, Owacja, Vineta, factor II - treatment methods involving the application of biostimulators and herbicide:

1. Standard treatment - mechanical treatment (without biostimulators and herbicide), 2. Prior to sprouting of potato plants - mechanical treatment and after sprouting - GreenOK Universal-PRO bioactivator, three times to leaves: at a dose of $0.10 \mathrm{dm}^{3} \mathrm{ha}^{-1}$ - peak-end of sprouting (phase BBCH 13-19) $+0.15 \mathrm{dm}^{3} \mathrm{ha}^{-1}$ - covering of interrows (phase BBCH 31-35) $+0.15 \mathrm{dm}^{3} \mathrm{ha}^{-1}-$ flower bud break (phase $\mathrm{BBCH}$ 51-55), 3. Prior to sprouting of potato plants - mechanical treatment, and after sprouting - Asahi SL bioactivator, three times to leaves at a dose of $0.50 \mathrm{dm}^{3} \mathrm{ha}^{-1}$ - peak-end of sprouting (phase BBCH 13-19) $+0.50 \mathrm{dm}^{3} \mathrm{ha}^{-1}$ 
- covering of interrows (phase BBCH 31-35) $+0.50 \mathrm{dm}^{3} \mathrm{ha}^{-1}-$ flower bud break (phase BBCH 51-55), 4. Prior to sprouting - mechanical treatment, and after the final shaping of ridges and just before sprouting Avatar $293 \mathrm{ZC}$ herbicide at a dose of $1.5 \mathrm{dm}^{3} \mathrm{ha}^{-1}$ (phase BBCH 00-05). After sprouting - three applications of GreenOK Universal-PRO bioactivator at a dose of $0.10 \mathrm{dm}^{3} \mathrm{ha}^{-1}$ - peak-end of sprouting (phase BBCH 13-19) $+0.15 \mathrm{dm}^{3} \mathrm{ha}^{-1}$ - covering of interrows (phase BBCH 31-35) $+0.15 \mathrm{dm}^{3} \mathrm{ha}^{-1}-$ flower bud break (phase BBCH 51-55), 5. Prior to sprouting - mechanical treatment, and after the final shaping of ridges before sprouting of potato plants - Avatar $293 \mathrm{ZC}$ herbicide at a dose of $1.5 \mathrm{dm}^{3} \mathrm{ha}^{-1}$ (phase $\mathrm{BBCH} 00-05$ ).

TheGreenOKUniversal-PROpreparation, according totheproducer'sinformation (Latvian Institute of Humic Substances), is a liquid organic fertiliser with biostimulating effect, consisting of humic substance concentrate $\left(\leq 20 \mathrm{~g} \mathrm{dm}^{3}\right)$ and NPK elements (0.13-0.09-0.7\%). The Asahi SL biostimulator contains three active ingredients from the nitrophenol group: sodium para-nitrophenol $-0.3 \%$, sodium ortho-nitrophenol $-0.2 \%$ and sodium 5 -nitroguaiacol $-0.1 \%$. These compounds occur naturally in plant cells and participate in physiological and biochemical processes of plants (Babuška 2004, Maciejewski et al. 2007). The Avatar 293 ZC herbicide applied in the experiment contains two active ingredients with a complementing mechanism of action. Clomazone is absorbed by roots and part of plants below cotyledons, it suppresses the synthesis of pigments in plants (chlorophyll and carotenoids). Metribuzin is absorbed by roots and leaves and suppresses the photosynthesis process (Label of the Avatar 293 ZC plant protection product).

Each year in autumn, before the experiments, natural fertilization was used at a dose of $25 \mathrm{tha}^{-1}$, as well as mineral fertilisation with phosphorus $44.0 \mathrm{~kg} \mathrm{P} \mathrm{ha}{ }^{-1}$ (triple superphosphate $46 \%$ ) and potassium $124.5 \mathrm{~kg} \mathrm{~K} \mathrm{ha}^{-1}$ (potassium salt $60 \%$ ), and during spring - nitrogen fertilisation (ammonium nitrate 34\%) at a dose of $100 \mathrm{~kg} \mathrm{~N}$ per 1 ha. Potato tubers were planted in the second decade of April (in 2015 and 2016) and in the third decade of April (in 2017). Protection treatment against diseases and pests was used in accordance with the plant protection recommendations. Harvest was performed in the phase of full technological maturity of tubers. Sample tubers from 10 potato plants (excluding edge plants) were taken randomly from every treatment of the experiment during harvest. The total yield was calculated on the basis of the mass of tubers harvested from a plot with an area of $20 \mathrm{~m}^{2}$. The content of dry matter was determined by means of the oven-dry method, that of starch on Reimann's balance. The yield of dry matter and starch of tubers was calculated as a product of total yield and the content of individual elements. 


\section{Statistical analysis}

The results of the study were subjected to statistical analysis using the method of the analysis of variance. Significance of variability sources was tested with the Fischler-Snedecor $F$ test, and the assessment of significance of differences at the significance level $p=0.05$ between the compared means using Tukey's range test (Trętowski and Wójcik 1988).

\section{Weather conditions}

Meteorological conditions in potato growing season are presented in Table 1. The data come from the Research Centre for Cultivar Testing (COBORU) in Stupia Wielka and were compiled for the Cultivar Assessment Experimental Station in Cicibór Duży, situated near Biała Podlaska. Meteorological conditions were diverse during the study period (Tab. 1). The highest precipitation sum was recorded in the growing season of $2017-425 \mathrm{~mm}$, in which mean air temperature was $15.4^{\circ} \mathrm{C}$; it was the coolest year in comparison with the other study years. The lowest precipitation sum - $288 \mathrm{~mm}$ - was recorded in 2015 with mean air temperature of $15.7^{\circ} \mathrm{C}$. In that season, a precipitation shortage occurred from June to August (i.e. during flowering, tuber formation and yield accumulation), while August was extremely dry with precipitation sum of $7 \mathrm{~mm}$ and high atmospheric air temperatures. The growing season of 2016 was characterised by precipitation sum at the level of $302 \mathrm{~mm}$, and air temperature was $16.1^{\circ} \mathrm{C}$, higher by $1.2^{\circ} \mathrm{C}$ than the mean air temperature from multi-year period (1990-2010); it was a favourable season for plant growth and yield accumulation.

Table 1. Meteorological conditions during the potato vegetation period in 2015-2017

\begin{tabular}{|c|c|c|c|c|c|c|c|}
\hline \multirow[b]{2}{*}{ Years } & \multicolumn{6}{|c|}{ Months } & \multirow{2}{*}{$\begin{array}{c}\text { Sum / Mean } \\
\text { IV-IX }\end{array}$} \\
\hline & IV & $\mathrm{V}$ & VI & VII & VIII & IX & \\
\hline \multicolumn{8}{|c|}{ Rainfalls (mm) } \\
\hline 2015 & 36 & 91 & 30 & 49 & 7 & 75 & 288 \\
\hline 2016 & 35 & 22 & 84 & 121 & 28 & 12 & 302 \\
\hline 2017 & 62 & 40 & 106 & 71 & 41 & 105 & 425 \\
\hline Average over the years $1990-2010$ & 38 & 61 & 60 & 77 & 68 & 57 & 361 \\
\hline \multicolumn{8}{|c|}{ Temperature $\left({ }^{\circ} \mathrm{C}\right)$} \\
\hline 2015 & 8.3 & 12.8 & 16.7 & 19.6 & 21.6 & 15.1 & 15.7 \\
\hline 2016 & 9.7 & 15.0 & 18.4 & 19.8 & 18.7 & 15.2 & 16.1 \\
\hline 2017 & 7.7 & 13.8 & 18.0 & 18.5 & 19.9 & 14.7 & 15.4 \\
\hline Average over the years $1990-2010$ & 8.3 & 13.9 & 17.0 & 19.4 & 18.3 & 12.7 & 14.9 \\
\hline \multicolumn{8}{|c|}{ *Sielianinov's hydrothermic coefficients } \\
\hline 2015 & 1.43 & 2.28 & 0.59 & 0.80 & 0.11 & 1.66 & 0.99 \\
\hline 2016 & 1.19 & 0.47 & 1.53 & 1.97 & 0.48 & 0.26 & 1.00 \\
\hline 2017 & 2.68 & 0.93 & 1.97 & 1.24 & 0.66 & 2.37 & 1.50 \\
\hline
\end{tabular}

*Coefficient value (Bac et al. 1998): < 0.5 - strong drought; 0.51-0.69 - semi drought; 0.70-0.99 poor drought; $\geq 1$ - fault drought 


\section{RESULTS AND DISCUSSION}

The size of the yield of dry matter and starch of potato tubers is determined mainly by the mass of harvested tubers and the concentration of the above-mentioned nutrients in them, which can be modified in a significant way by individual experimental factors.

As a result of the study it was proved that the selected treatment methods, applied potato cultivars cultivated in the experiment, as well as meteorological conditions that prevailed in particular research years had a significant impact on the size of the yield of dry matter and starch of tubers (Tabs 2-5).

Table 2. Yield of dry matter of potato tubers $\left(\mathrm{t} \mathrm{ha}^{-1}\right)$ depending on cultivation methods and potato cultivars

\begin{tabular}{lccccc}
\hline \multirow{2}{*}{ Methods } & \multicolumn{3}{c}{ Cultivars } & \multirow{2}{*}{ Mean } \\
\cline { 2 - 5 } $1 . *$ & Owacja & Bellarosa & Vineta & \\
\hline 2. & 6.8 & 5.5 & 6.9 & 6.4 \\
3. & 8.5 & 6.6 & 8.6 & 7.9 \\
4. & 8.8 & 6.9 & 8.9 & 8.2 \\
5. & 9.7 & 7.7 & 9.6 & 9.0 \\
Mean & 9.2 & 7.4 & 9.2 & 8.6 \\
$* *$ LSD $_{0.05}$ for: & 8.6 & 6.8 & 8.6 & 8.0 \\
& & & & \\
& cultivars & & & & 0.254 \\
& methods & & & & n.s. \\
\hline
\end{tabular}

* - as in the experiment's methodology, ${ }^{*} \mathrm{LSD}_{0.05}$ - least significant difference, n.s. - not significant

The cultivation methods applied in the experiment with the use of growth biostimulators and herbicide caused a significant increase in the yield of dry matter and starch of potato tubers (treatments 2-5) in comparison with mechanical treatment alone (treatment 1.) (Tabs 2 and 3). The highest yield of dry matter and starch was obtained in treatment 4 (where mechanical treatment was used prior to sprouting and then Avatar $293 \mathrm{ZC}$ herbicide at a dose of $1.5 \mathrm{dm}^{3} \mathrm{ha}^{-1}$, and GreenOK UniversalPRO bioactivator at a dose of $0.10 \mathrm{dm}^{3} \mathrm{ha}^{-1}+0.15 \mathrm{dm}^{3} \mathrm{ha}^{-1}+0.15 \mathrm{dm}^{3} \mathrm{ha}^{-1}$ three times after sprouting) (on average $9.0 \mathrm{t} \mathrm{ha}^{-1}$ of dry matter and $6.3 \mathrm{t} \mathrm{ha}^{-1}$ of starch) and in treatment 5, where mechanical treatment was used and then the Avatar 293 $\mathrm{ZC}$ herbicide at a dose of $1.5 \mathrm{dm}^{3} \mathrm{ha}^{-1}$. The mean yields of nutrients obtained in treatment 5 were $8.6 \mathrm{t} \mathrm{ha}^{-1}$ of dry matter and $6.0 \mathrm{t} \mathrm{ha}^{-1}$ of starch, respectively (Tabs 2 and 3). The results are in accordance with the research of Trawczyński (2014) who obtained an average increase of yield by $13.8 \%$ after the application of the Tecamin biostimulator. Gugała et al. (2017) obtained the highest rise in the yield of potato tubers applying the Sencor 70 WG herbicide just before sprouting and then 
the Asahi SL biostimulator twice. In the research carried out by Rudzińska-Mękal (2000), biostimulators Mival and Moddus $250 \mathrm{ME}$ increased the content of starch by $1.5-3.3 \%$. Also Sawicka and Krochmal-Marczak (2009) reported an increase in the content of dry matter and starch upon the application of growth stimulators in potato cultivation. Moreover, a beneficial impact of the growth stimulators Asahi SL, Bio-Algeen S90 and Kelpak in potato cultivation was noted in the research conducted by Wierzbowska et al. (2015). However, Maciejewski et al. (2007) stated, on the basis of two-year research, that the Asahi SL and Atonik biostimulators applied in their experiment had no impact on the content of dry matter and starch in tubers of three edible potato cultivars.

Table 3. Yield of starch of potato tubers $\left(\mathrm{t} \mathrm{ha}^{-1}\right)$ depending on cultivation methods and potato cultivars

\begin{tabular}{|c|c|c|c|c|}
\hline \multirow{2}{*}{ Methods } & \multicolumn{3}{|c|}{ Cultivars } & \multirow{2}{*}{ Mean } \\
\hline & Owacja & Bellarosa & Vineta & \\
\hline 1. * & 4.9 & 3.8 & 4.7 & 4.5 \\
\hline 2. & 6.0 & 4.5 & 5.9 & 5.5 \\
\hline 3. & 6.2 & 4.6 & 6.1 & 5.6 \\
\hline 4. & 6.8 & 5.4 & 6.8 & 6.3 \\
\hline 5. & 6.5 & 5.0 & 6.4 & 6.0 \\
\hline Mean & 6.1 & 4.7 & 6.0 & 5.6 \\
\hline \multicolumn{5}{|l|}{$* * \mathrm{LSD}_{0.05}$ for: } \\
\hline \multicolumn{2}{|c|}{ cultivars } & & & 0.190 \\
\hline \multicolumn{2}{|c|}{ methods } & & & 0.189 \\
\hline \multicolumn{2}{|c|}{ cultivars $\mathrm{x}$ methods } & & & n.s. \\
\hline
\end{tabular}

* - as in the experiment's methodology, ${ }^{* *} \mathrm{LSD}_{0.05}$ - least significant difference, n.s. - not significant

The obtained results of the study proved that potato cultivars cultivated in the experiment had a significant impact on the size of the yield of dry matter and starch of tubers (Tabs 3 and 4). Sawicka et al. (2011), Wierzbicka (2012), Kołodziejczyk (2013), Barabaś and Sawicka (2016) inform about the effect of genetic features of cultivars on the content and yield of dry matter and starch of tubers. In the experiment, potato cultivars modified the yield of dry matter and starch from a unit of area in a significant way. Significantly lower yield of the nutrients discussed was recorded when the Bellarosa cultivar was cultivated (on average $6.8 \mathrm{t} \mathrm{ha}^{-1}$ of dry matter and $4.7 \mathrm{t} \mathrm{ha}^{-1}$ of starch) (Tabs 2 and 3). The yield of the nutrients in the Owacja and Vineta cultivars was similar. According to Krzysztofik (2009), the content of nutrients in tubers is a cultivar feature, but with a right size of yield, cultivars with a lower content of nutrients can yield a crop on a comparable level or higher than cultivars with lower yields but higher concentration of nutrients. It was confirmed in this study. 
From the conducted studies it appears that the yield of dry matter and starch of tubers was significantly diversified in individual research years (Tab. 4 and 5). The lowest yields of the nutrients discussed were obtained in the humid growing season of 2017, in which the precipitation sum was $425 \mathrm{~mm}$, being higher than the mean sum from the multi-year period by $64 \mathrm{~mm}$. However, a significantly higher yield of the nutrients discussed was recorded in the growing season of 2016, in which atmospheric conditions were the most favourable for the growth and development of potato plants in comparison with the other research years. The results are in accordance with the research of Gugała and Zarzecka (2010), Rymuza et al. (2015) and Skowera and Puła (2004) who proved that weather conditions in individual research years, especially the amount of precipitation, were the factor differentiating the content of dry matter and starch in potato tubers. Lower accumulation of dry matter and starch in tubers was observed in years with the highest amount of precipitation than in other research years.

Table 4 . Yield of dry matter of potato tubers $\left(\mathrm{tha}^{-1}\right)$ depending on cultivation methods and research years

\begin{tabular}{lccccc}
\hline \multirow{2}{*}{ Methods } & \multicolumn{3}{c}{ Year } & \multirow{2}{*}{ Mean } \\
\cline { 2 - 4 } $1 . *$ & 2015 & 2016 & 2017 & \\
\hline 2. & 6.0 & 7.2 & 6.0 & 6.4 \\
3. & 7.7 & 8.7 & 7.2 & 8.9 \\
4. & 8.3 & 9.0 & 7.4 & 8.2 \\
5. & 9.1 & 9.8 & 8.0 & 8.6 \\
Mean & 8.6 & 9.4 & 7.7 & 8.0 \\
$* *$ LSD $_{0.05}$ for: & 7.9 & 8.8 & 7.3 & \\
& & & & 0.254 \\
& years & & & & 0.254 \\
& methods & & & n.s. \\
\hline
\end{tabular}

${ }^{*}$ - as in the experiment's methodology, ${ }^{* *} \mathrm{LSD}_{0.05}$ - least significant difference, n.s. - not significant

Table 5. Yield of starch of potato tubers $\left(\mathrm{t} \mathrm{ha}^{-1}\right)$ depending on cultivation methods and research years

\begin{tabular}{lccccc}
\hline \multirow{2}{*}{ Methods } & \multicolumn{3}{c}{ Year } & \multirow{2}{*}{ Mean } \\
\cline { 2 - 5 } $1 . *$ & 2015 & 2016 & 2017 & 4.5 \\
2. & 4.2 & 5.1 & 4.2 & 5.4 \\
3. & 5.1 & 6.1 & 5.1 & 5.7 \\
4. & 5.5 & 6.3 & 5.2 & 6.3 \\
5. & 6.3 & 7.0 & 5.7 & 6.0 \\
Mean & 5.8 & 6.7 & 5.5 & 5.6 \\
$* *$ LSD $_{0.05}$ for: & 5.4 & 6.2 & 5.1 & \\
& & & & 0.190 \\
& years & & & & 0.189 \\
& methods & & & n.s. \\
\hline
\end{tabular}

* - as in the experiment's methodology, ${ }^{* *} \mathrm{LSD}_{0.05}-$ least significant difference, n.s. - not significant 


\section{CONCLUSIONS}

1. The yield of dry matter and starch of edible potato tubers depended significantly on the cultivation methods. Growth biostimulators and herbicide applied in the experiment had a positive impact on obtaining higher yields of dry matter and starch of tubers in comparison with the control object treated only mechanically.

2. The most effective cultivation method for potato in terms of the size of the yield of nutrients was the use of mechanical treatment prior to sprouting of plants, and just before sprouting, the Avatar $293 \mathrm{ZC}$ herbicide at a dose of $1.5 \mathrm{dm}^{3} \mathrm{ha}^{-1}$, and after sprouting three applications of the GreenOK Universal-PRO bioactivator at a dose of: $0.10 \mathrm{dm}^{3} \mathrm{ha}^{-1}+0.15 \mathrm{dm}^{3} \mathrm{ha}^{-1}+0.15 \mathrm{dm}^{3} \mathrm{ha}^{-1}$ (treatment 4) and using mechanical treatment prior to sprouting and the Avatar 293 ZC herbicide at a dose of $1.5 \mathrm{dm}^{3} \mathrm{ha}^{-1}$ just before sprouting (treatment 5).

3. Genetic features of potato cultivars had a significant impact on the size of the yield of dry matter and starch of tubers. The lowest yield of the nutrients discussed was recorded in the Bellarosa cultivar.

4. Higher yields of dry matter and starch of tubers were obtained in the growing season of 2016, in which atmospheric conditions were the most favourable for the growth and development of potato plants in comparison with the other research years.

\section{REFERENCES}

Bac S., Koźmiński Cz., Rojek M., 1998. Agrometeorology (in Polish). PWN, Warsaw.

Barbaś P., Sawicka B., 2016. Impact of the methods of removing weeds on the content and yield of dry matter and starch in tubers of two potato cultivars (in Polish). Fragm. Agron., 33(4), 7-17.

Bishwoyog B., Swarnima K.C., 2016. Effect of potassium on quality and yield of potato tubers -a review. International Journal of Agriculture \& Environmental Science, 3, 9-14.

Camire M.E., Kubow S., Donnelly D.J., 2009. Potatoes and human health. Critical Reviews in Food Science and Nutrition, 49(10), 823-840, doi:10.1080/10408390903041996

Gabriel W., Świeżyński K., 1977. Potato cultivation and seed production (in Polish). PWRiL, Warsaw.

Grudzińska M., Czerko Z., Wierzbicka A., Borowska-Komenda M., 2016. Changes in the content of reducing sugars and sucrose in tubers of 11 potato cultivars during storage at the temperature of 5 and $8^{\circ} \mathrm{C}$ (in Polish). Acta Agroph., 23(1), 31-38.

Gugała M., Zarzecka K., 2010. The influence of herbicides on the content of dry matter, protein and starch in potato tubers (in Polish). Biul. IHAR, 257/258, 111-119.

Gugała M., Zarzecka K., Sikorska A., Mystkowska I., Dołęga H., 2017. The impact of herbicides and growth biostimulants on reduced weeding and yielding of edible potato (in Polish). Fragm. Agron., 34(4), 59-66.

Plant Breeding and Acclimatization Institute - National Research Institute, 2015. Characteristics

Kołodziejczyk M., 2013. Phenotypic variation of yield, chemical composition and selected qualitative features of medium late tubers (in Polish). Acta Agroph., 20(3), 411-422.

Krzysztofik B., 2009. The impact of farming on the degree of alignment of the size of potato tubers and the yield of starch (in Polish). Acta Agroph., 14(2), 355-365. 
Lamberti M., Geiselmann A., Conde-Petit B., Escher F., 2004. Starch transformation and structure development in production and reconstitution of potato flakes. LWT - Food Sci. Technol., 37(4), 417-427.

Leszczyński W., 2004. Resistant starch - classification, structure, production. Pol. J. Food Nutr. Sci., 13(54), SI 1, 37-50.

Leszczyński W., 2012. Nutritional value of potato and potato products (in Polish). Biul. IHAR, 266, 5-20.

Lisińska G., 2000. Raw material and technological factors shaping the quality of potato products. Scientific Conference Materials. Potato intended for consumption and industrial use and its processing (in Polish). Polanica Zdrój, November 8th, 51-59.

Lutaladio N.B., Castaldi L., 2009. Potato: The hidden treasure. J. Food Comp. Anal., 22, 491-493, doi:10.1016/j.jfca.2009.05.002

Maciejewski T., Szukała J., Jarosz A., 2007. The impact of the Asahi SL and Atonik SL biostimulants on qualitative characteristics of potato tubers (in Polish). J. Res. App. Agric Eng., 52(3), 109-112.

Marle T. van, Stolle-Smits T., Donkers J., Dijk V. van, Voragen A.G.J., Recourt K., 1997. Chemical and microscopic characterization of potato (Solanum tuberosum L.) cell walls during cooking. J. Agric. Food Chem., 45(1), 50-58, doi:10.1021/jf960085g

Matyjaszczyk E., 2015. Introduction of biostimulants to the market in Poland. Current situation and legal conditions (in Polish). Przemysł Chemiczny, 94(10), 1841-1844.

Paradikovic N., Vinkovic T., Vrcek I.V., Zuntar I., Bojic M., and Medic-Saric M., 2011. Effect of natural biostimulants on yield and nutritional quality: an example of sweet yellow pepper (Capsicum annuum L.) plants. J. Sci. Food Agric., 91, 2146-2152.

Pszczółkowski P., Sawicka B., 2018. The effect of application of biopreparations and fungicides on the yield and selected parameters of seed value of seed potatoes. Acta Agroph., 25(2), 239-255, doi:10.31545/aagr/93104

Puła J., Skowera B., 2004. Variability of qualitative characteristics of potato tubers of the Mila cultivar grown on light soil depending on weather conditions (in Polish). Acta Agroph., 3(2), 359-366.

Rudzińska-Mękal B., 2000. Modification of the chemical composition of potato tubers by synthetic growth regulators Mival and Moddus 250 ME. Doctoral thesis. Wydz. Rol. AR w Lublinie, 1-137.

Rymuza K., Radzka E., Lenartowicz T., 2015. The impact of environmental conditions on the content of starch in tubers of medium early potato cultivars (in Polish). Acta Agroph., 22(3), 279-289.

Sawicka B., Krochmal-Marczak B., 2009. Effects of combined application of foliar fertilizers and growth biostimulators in cultivation of new potato cultivars. Annales UMCS, Sec. E, 64(2), 29-38.

Sawicka B., Michałek W., Pszczółkowski P., 2011. Determinants of yield potential of medium late and late potato cultivars in the conditions of Central-Eastern Poland (in Polish). Biul. IHAR 259, 219-228.

Sawicka B., Noaema A.H., Kiełtyka-Dadasiewicz A., Barbaś P., 2016. Nutritional value of potato tubers in the conditions of application of growth bioregulators. In: Bioproducts - acquisition, properties and application in food production (in Polish) (Eds G. Lewandowicz, J. Le ThanhBlicharz). Faculty of Food Science and Nutrition of the Poznań University of Life Sciences, 65-73.

Trawczyński C., 2014. The impact of amino acid-based biostimulant - Tecamin - on the yield and quality of potatoes (in Polish). Ziemniak Polski, 3, 29-34.

Trawczyński C., 2016. The impact of cultivar and weather conditions during the vegetation period on the content of selected nutrients and anti-nutrients in potato tubers (in Polish). Acta Agroph., 23(1), 119-128.

Trętowski J., Wójcik R., 1988. Methodology of agricultural experiments (in Polish). WSRP Publishing House, Siedlce.

Wierzbicka A., 2012. The impact of cultivar, nitrogen fertilization and date of harvest on the content of dry matter and starch in tubers of early potatoes (in Polish). Fragm. Agron., 29(2), 134-142. 
Wierzbowska J., Cwalina-Ambroziak B., Głosek-Sobieraj M., Sienkiewicz S., 2015. Effect of biostimulators on yield and selected chemical properties of potato tubers. J. Elem., 20(3), 757-768, doi:10.5601/jelem.2014.19.4.799

Zarzecka K., Gugała M., 2013. The effects of soil fertilizer UGmax on yield of potato tubers and its structure (in Polish). Biul. IHAR, 267, 107-112.

Zgórska K., Frydecka-Mazurczyk A., 2002. Standards and quality requirements of edible potato and potato intended for food processing. In: Production and market of edible potato (in Polish) (Ed. J. Chotkowski). Wieś Jutra, 183-192.

Zgórska K., Grudzińska M., 2012. Changes in selected quality characteristics of potato tubers during storage (in Polish). Acta Agroph., 19(1), 203-214.

\section{PLON SUCHEJ MASY I SKROBI BULW ZIEMNIAKA JADALNEGO W WARUNKACH STOSOWANIA BIOSTYMULATORÓW WZROSTU I HERBICYDU}

\section{Alicja Joanna Baranowska}

Zakład Rolnictwa, Katedra Nauk Technicznych, Wydział Nauk Ekonomicznych i Technicznych Państwowa Szkoła Wyższa im. Papieża Jana Pawła II w Białej Podlaskiej

ul. Sidorska 95/97, 21-500 Biała Podlaska

e-mail: alabar@tlen.pl

Streszczenie. Doświadczenia polowe przeprowadzono w latach 2015-2017 w rejonie Polski wschodniej, w gminie Biała Podlaska $\left(52^{\circ} 02^{\prime} \mathrm{N}, 23^{\circ} 07^{\prime} \mathrm{E}\right)$, w województwie lubelskim. Celem badań było określenie wpływu metod pielęgnacji z zastosowaniem biostymulatorów wzrostu i herbicydu na plon suchej masy i skrobi bulw ziemniaka jadalnego. Eksperyment założono metodą losowanych podbloków w trzech powtórzeniach. Badanymi czynnikami były: I czynnik - trzy wczesne odmiany ziemniaka jadalnego (Owacja, Bellarosa, Vineta), II czynnik - dawki i terminy aplikacji biostymulatorów wzrostu: GreenOk-Uniwersal Pro i Asahi SL oraz ich kombinacja z herbicydem Avatar 293 ZC. Największy plon suchej masy bulw i skrobi uzyskano na obiekcie 4., na którym do wschodów zastosowano pielęgnację mechaniczną, a po ostatecznym ukształtowaniu redlin tuż przed wschodami herbicyd Avatar $293 \mathrm{ZC}$ w dawce $1.5 \mathrm{dm}^{3} \cdot \mathrm{ha}^{-1}$, następnie po wschodach trzykrotnie aplikowano bioaktywator GreenOK Universal-PRO w dawkach: $0.10 \mathrm{dm}^{3} \cdot \mathrm{ha}^{-1}$ - pełnia-koniec wschodów $+0.15 \mathrm{dm}^{3} \cdot \mathrm{ha}^{-1}-$ zakrywanie międzyrzędzi $+0.15 \mathrm{dm}^{3} \cdot \mathrm{ha}^{-1}-$ zawiązywanie pąków kwiatowych (średni plon suchej masy kształtował się na poziomie: 9.0 i $6.3 \mathrm{t} \cdot \mathrm{ha}^{-1}$ skrobi). Natomiast najmniejsze plony składników odżywczych bulw ziemniaka uzyskano na obiekcie, na którym stosowano wyłącznie pielęgnację mechaniczną (obiekt 1). Na wielkość plonu suchej masy bulw i skrobi istotny wpływ miały również uprawiane w doświadczeniu odmiany ziemniaka oraz warunki meteorologiczne. Biostymulatory wzrostu powinny znaleźć szersze zastosowanie w praktyce rolniczej ponieważ są to preparaty przyjazne środowisku oraz ich stosowanie na plantacjach roślin rolniczych przynosi wymierne korzyści produkcyjne.

Słow a kluczowe: ziemniak, metody pielęgnacji, GreenOk-Uniwersal Pro, Asahi SL, Avatar 293 ZC 